\title{
SHARJAH'S ISLAMIC URBAN IDENTITY AND THE LIVING CITY
}

Mohamed El-Amrousi

John Biln
Department of Architectural Engineering, College of

Engineering, United Arab Emirates University PO. Box 17555, Al Ain, UAE

e-mail: melamrosi@uaeu.ac.ae

Department of Architectural Engineering, College of Engineering, United Arab Emirates University PO. Box 17555, Al Ain, UAE

e-mail: biln@uaeu.ac.ae

\begin{abstract}
Prominently placed amidst open gardens and along the waterfront of the Sharjah Corniche, several recent monumental buildings collectively suggest a new urban image and socio-cultural space for a modern Muslim urban identity. Along with a series of restaurants, entertainment spaces, and office building, Masjid al-Noor, Masjid al-Maghfira, Al-Qasbah, and the Museum of Islamic Civilization house important cultural institutions, combining eclectic references to the history of Islam into a new urban order. Neither entirely the conservative vernacularism of whole-scale historical mimicry, nor altogether the neo-vernacularism of fragmentary pastiche, this urban assemblage embraces these two distinct design approaches at the level of the individual buildings, but unifies them at the urban scale in what could be called neo-regional urbanism. The stylistic clarity of Masjid al-Noor, which consistently integrates the stylistic elements of Ottoman styled mosques, contrasts with the isolated fragments of Moorish/Hispanic lattice work that adorn the otherwise modern Masjid al-Maghfira. Al-Qasbah's neo-Islamic horse-shoe arches contrast with the Syrian-Ottoman styled facades of the Museum of Islamic Civilization. Although these buildings individually address the problems of built form and the application of Islamic ornaments disparate ways, taken together this group of new monuments forms a complex urban whole that serves to reflect and deepen an emerging sense of identity that is built upon a similarly complex mix of multicultural non-western ethnicities that make up the fluid and mobile population of Sharjah. This urban assemblage has become such a popular space of gathering that it has begun to shift the centre of gravity of Sharjah's urban social space towards the Corniche, and in so doing has produced an authentic alternative to the introverted malls and isolated dreamscapes of Dubai. This paper studies the strategies and effects of this assemblage of neo-Islamic monuments in Sharjah, and considers how it effectively rethinks the possibilities of the contemporary Arab city.
\end{abstract}

Keywords: Urban identity, Sharjah, Muslim heritage, Arab culture

\begin{abstract}
Abstrak
Ditempatkan secara mencolok di tengah-tengah taman terbuka dan sepanjang pantai di Corniche Sharjah, beberapa bangunan monumental baru secara kolektif mempertunjukkan gambaran urban baru dan ruang sosial- budaya bagi identitas urban Muslim modern. Beriringan dengan serangkaian restoran, tempat-tempat pertunjukan, dan gedung perkantoran, Masjid al-Noor, Masjid al-Maghfira, Al-Qasbah, dan Museum Peradaban Islam menempati posisi sebagai institusi budaya yang penting, menggabungkan referensi-referensi eklektik dengan sejarah Islam menjadi sebuah tatanan urban baru. Baik sepenuhnya vernakularisme konservatif dari keseluruhan mimikri sejarah, ataupun merupakan neo-vernakularisme yang berupa campuran dari berbagai fragmen, kumpulan urban ini mengadopsi dua pendekatan desain yang berbeda pada tingkat bangunan individual, namum menyatukan mereka pada skala perkotaan dalam apa yang dapat disebut sebagai urbanisme neo-regional. Kejelasan gaya dari Masjid al-Noor, yang secara konsisten mengintegrasikan elemen-elemen gaya masjid bergaya Ottoman, menciptakan kontras dengan fragmen terisolasi dari karya kisi-kisi bergaya Moor/ Hispanik yang menghiasi Masjid modern al-Maghfira. Al-Qasbah dengan pelengkung tapal kuda dari neo-Islam menciptakan kontras dengan fasad bergaya Suriah-Ottoman dari Museum Peradaban Islam. Meskipun secara individu bangunan-bangunan ini mengalami permasalahan dalam penerapan bentuk dan ornamen Islam dalam berbagai cara yang berbeda, ketika disatukan kelompok monumen baru ini membentuk suatu kompleks urban yang mencerminkan dan memperdalam kemunculan rasa identitas yang dibangun di atas kesamaan percam- puran kompleks dari etnis multikultural non-Barat yang membentuk populasi Sharjah yang cair dan berge- rak. Kumpulan urban ini telah menjadi semacam ruang populer untuk berkumpul yang telah mulai menggeser pusat gravitasi ruang sosial kota Sharjah ke arah Corniche, dan dengan demikian telah menghasilkan alternatif otentik dari mal-mal yang tertutup dan ruangruang impian yang terisolasi di Dubai. Tulisan ini mempelajari strategi dan dampak dari himpunan monumen neo-islam di Sharjah, dan mempertimbangkan bagaimana hal tersebut dapat secara efektif menjadi renungan kembali dari berbagai kemungkinan kota Arab kontemporer.
\end{abstract}

Kata kunci: Sharjah, pusaka Muslim, identitas urban, budaya Arab

190 | Journal of Islamic Architecture Volume 1 Issue 4 December 2011 



\section{Introduction}

The Dubai that presents itself to the casual observer engaging in business or tourist activities typical of the greater Dubai-Sharjah metropole appears to comprise little more than massive malls, glass towers, and luxury hotels. Closer observation reveals densely packed but modest commercial enterprises, and nearer the city peripheries, busy industrial zones comprised of car dealerships, small automobile repair shops and light industrial plants. Visitors crossing from Dubai's industrial areas toward the Sharjah Corniche along the unmarked boundary between these two cities are offered a very different urban experience. From a shoreline approach, there is an immediate shift to a vibrant and living urban ensemble signifying an urban modernity composed of carefully marked off culturally significant monuments reserved for contemplation, combined with popular places of quotidian activity supporting patterns of social-cultural behaviour that appeal to local residents.

Sharjah's waterfront landscape includes large open gardens visible from different perspectives as one crosses from one lagoon to another, interlaced with iconic secular and religious buildings and recreational spaces reflecting a new interpretation of regionalism as an architectural strategy. New materials and significant attention to details and fragments of architecture deriving from across the greater Arab region support an urban assemblage that signal the city as a living organism, a manifestation of spaces of culture rather than spaces of shallow consumption clad with weak pastiches of visual signs loosely de- rived from a vast range of Muslim buildings, regions and timeframes. Masjid al-Noor with its clearly marked Ottoman style, Masjid al-Maghfira with its eclectic referential to Alhambra's interlacing stalactites, and Al-Qasbah with its Moorish Hispanic Horseshoe arches, together mark out a new spatial matrix that preserves clearly identifiable references to iconic monuments and institutions that together form the broad cultural unconscious of Sharjah's local resident mix. The new monuments along Sharjah's Corniche enliven a shared "memory" of historic ornament accumulated over time and preserved in decorative motifs such as Arabesques, textured stucco, tile-mosaic and marble inlay. The evocative power of these motifs derive from much more than their superficial signvalue, residing in large part in their physicality and craft preserved in the rare expertise of the trained craftsmen assembled to re-manifest them. In the Masjid al-Noor, Masjid al-Maghfira, Al-Qasba, and the Museum of Islamic Civilization along Sharjah's waterfront, an unexpected but entirely inescapable sense of historical authenticity sits alongside unselfconscious open air social interaction. The power of the neoIslamic monuments and activity spaces comprising this Sharjah waterfront derives from a profoundly reassuring sense of belonging produced in the combination of deep cultural resonance and reassuringly familiar everyday activity.

For the predominantly Arab and Muslim expatriate workers who frequent this area, the Sharjah Corniche offers a comforting respite from the divisive social/class constraints and politics of exclusion characterizing the high-end resorts and theme malls for which greater Dubai is known. In contrast to the gentrification that has occurred in this frenetic city, Sharjah's waterfront offers a genuinely new alternative rooted in a unique and finely calibrated assemblage of iconic imagery and social space. On the surface, the idea here of combining explicit architectural references to a wide swath of historical Islam appears similar to some modernist and a great many post modernist compositional strategies, in the sense that in this contemporary revival of existing forms there is still an insistence on dissolving any sense of privileged "origin". Here, the now neo-Islamic monument becomes a contemporary and integral part of the modern city fabric. In so doing, however, it refuses to give up a sense of "authenticity" that most of postmodernity has rejected. In Sharjah, we see a model of authenticity that reaches forward to contemporary Arab/Muslim social life and down into a shared and living cultural unconscious rooted in Islam, but rejects the backward gaze that seeks some pre-existing meaning delimited by the historical "truth" of some specific moment. Resonant fragments of history are deployed here to activate a heritage whose meaning cannot be divorced from the spaces of contemporary social gathering that surround and interlace with the monumental "memory machines" of Masjid al-Noor, Masjid al-Maghfira, Al-Qasba, and the Museum of Islamic Civilization. Here we can find a model of meaningful urban development built around an assemblage of hybrid Muslim decorative motifs which themselves developed over time, and which function at once to reinforce the diverse cultural identities of expatriates in Sharjah, while building a contingent sense of cultural and social community through the support of simple everyday activity. Under broad notion of "regional expression", the Sharjah Corniche suggests that a meaningful new urbanism can be created where contemporary life is allowed to unfold in the shadow of deeply historical and culturally resonant monuments. 
The Modern Arab City: Cultural Identity, Signification, and Problems of Style

In a very real sense, the approach taken along the Sharjah Corniche cannot be properly understood without placing it in the larger context of regional urbanism. The modern Arab city has its roots in Beaux Arts neo-Classical design principles which involved the suppression of function and meaning in favour of sets of architectural signs and fragments of various historical styles made available, through disaggregation and recombination, into new formal compositions. Whatever value this approach had for the production of monumental architecture was immediately undercut by the accompanying loss of any cultural meaning directly relevant to the lives of the urban population these buildings served. The resultant distancing of architectural form and detail from immediate social and cultural contexts effectively robbed architecture of its potential to support representational functions serving emergent political agendas, as well as its potential to satisfy broader cultural demands for identity, community and the continuities of tradition that could be lived and experienced via built form.

These difficulties were recognized by Hassan Fathy who in 1960s Egypt developed an alternative architecture intimately bound to its surrounding environment. In stark contrast to inherited compositionbased strategies, it was neither formally abstract nor divorced from the realities of place and social life. Indeed it was unashamedly local and culturally conservative. Over more than half a century, Fathy devoted his professional life to traditional technology, local materials, and intimate contact with the natural environment in a form of conservative vernacularism that proved highly influential. Over time, Fathy moved from local materials such as mud brick and related vernacular techniques to more durable materials such as stone and necessarily higher levels of skill and craftsmanship. This shift increased the disciplinary acceptability of such design approaches, but, at the same time, cost considerations tended to limit the scope of application of these revived materials and building crafts to a small number of admittedly fine private residences for wealthy families. Beyond this, Hassan Fathy emphasis on nostalgia and revival based largely on rural building traditions tended to bracket any sort of active engagement with modernity and approaches to construction. He also paid insufficient attention to evolving patterns of urban life and changing social expectations. In general, Hassan Fathy's design approach, however admirable from a traditionalist point of view, remained distant from the modernity in which that work was inescapably embedded.
Nonetheless, Hassan Fathy's ground-breaking attempt at localisation prompted others to consider related regionalist alternatives. In South Asia, Charles Correa sought an architecture sensitive to the climate with his slogan "form follows climate", clearly a provocative restatement of Mies van der Rohe's "form follows function" motto, and a signal recrafting of Mies's sentiments. Correa's three word manifesto succinctly captured an emerging desire to couple architectural modernism with appropriate regional responses. In Turkey, Sedad Eldem similarly sought a modern identity for the traditional Turkish house, attempting to engage both modernity and tradition in a single design strategy. One of the most compelling regionalist responses of this type, and perhaps the one in some ways most similar to the Sharjah Corniche development with which we are concerned, was offered by Fathy's disciple, Abdel Wahed El-Wakil, who designed an influential series of Cairene Mamluk inspired mosques along the Corniche of Jeddah. Notably, domes and sections of the façade of the mosque of Sultan Hassan (1356) can be seen on the King Saud Mosque in Al-Sharafeyyah in Jeddah. El-Wakil's Corniche mosques effectively re-introduced the mosque as modern sculpture to Gulf States in the $1980 \mathrm{~s}^{1}$. Although building on Mamluk forms, they evidence a blurring of stylistic boundaries. El-Wakil insisted on the possibility of transplanting stylistically distinctive monuments beyond national boundaries in order to create stylistically charged religious spaces unrelated to locality or local community. El-Wakil understood that it was necessary to preserve and reassert important cultural references by incorporating these into the architectonic layers of a historic monument. $\mathrm{He}$ also understood that the monument must be produced in such a way that it meaningfully engaged modern building materials, technologies, and the condition of the modern city more generally.

Rifat Chadirji in Baghdad also sought to develop a culturally rich architectural idiom that would bring tradition and modernity into contact. His approach was to focus attention on a building facade that could carry explicit and wide-ranging references to the architectural heritage of Iraq, and beyond, while accommodating modern advance in building technology. Both his Islamic Bazaar and his Museum of Islamic Civilization make extensive use of glazed tiles on their vaulted roofs, while the Museum further adds typically alternating black and white stonework. In general, Chadirji's work in Iraq and the Gulf exemplifies a wide range modern styles and materials, with formal references ranging from a catalogue of central Asian architectural traditions to details and forms characteristic of the iconic monuments of Spanish and 
Moroccan Islam. Suha Ozkan refers to this approach as "neo-vernacular", a term that attempts to captures the essence of an approach that freely draws on a wide range of historical sources while incorporating contemporary building approaches ${ }^{2}$.

Rifat Chadirji's work is significant here not only for a fusing of eclectic historical references with modern materials and technologies, but also for its active engagement with the social and political contexts within which it finds itself. This is most clearly expressed in Chadirji's use of non-traditional building materials such as reinforced concrete and an advocacy of multiple methods of constructing traditional forms, a strategy promoted by French architects in Casablanca, and Rabat in Morocco. In the 1950's, political liberation was endowed with socialist ideology, and Chadirji's use of new materials, such as reinforced concrete, to render decorative details carried with it both a pragmatic recognition of changing political landscapes, and the sense that the emerging revolutionary state was both patron and inheritor of long-standing cultural and religious traditions in the region.

Despite their attempts to build on Hassan Fathy's work and to produce a socially relevant Arab architecture that could link history and tradition to contemporary technological and political realities, a significant problem with El-Wakil's and Chadirji's body of work is that in acknowledging and embracing the "freefloating" mobility of details, references, styles, and even whole buildings that is occurring under globalization, this work has done little to challenge the contemporary fever to construct urban settings that often appear entirely authentic and which sometimes seem to have as much or more aesthetic force and presence as the originals from which they derive ${ }^{3}$. In large part, such replication strategies are deployed in order to satisfy tourists seeking "real" experiences while they remain safely isolated from the real city. There is little in El-Wakil's and Chadirji's design strategy of eclectic sampling that inherently resists the appropriation of built form for the purposes of increasing tourist revenue or validating some unified national narrative of culture, place and identity ${ }^{4}$. Indeed, as we saw, Chadirji's design approach takes precisely this type of form-ideology mapping for granted, although Chadirji himself attempts to control which political ideologies may be mapped onto his stylistic mixes. It is not, of course, necessary that architects such El-Wakil and Chadirji stake out any form of resistance to the economically or politically driven mis-appropriation of architecture, but it remains a problem with such approaches that as they leave open possibilities for what we might call "inter- pretive misuse", they at the same time fail to produce viable ground conditions for the production of authentic meaning among their local audiences. Ultimately, both these problems derives from the tendency in ElWakil's and Chadirji's work to hold onto the prejudices and biases inherited from an architectural discipline that was and continues to be at its heart "representational", and therefore always somewhat disconnected from the practicalities of urban life. It is on the basis of their ability to transcend the limitations of purely representational design strategies, while utilizing those same representational strategies, in concert with their collective attempt to embrace and animate socio-cultural practices, that the monuments and spaces of the Sharjah Corniche effectively work to resolve these difficulties and, in so doing, to reinforce contemporary Arab/Muslim identity and local cultural cohesion in Sharjah.

\section{Sharjah's Masjid al-Noor, Modern Icons and Historic Reference}

Designed by the Architectural Academic Office and constructed by United Engineering, Sharjah's Masjid al-Noor was completed in 2005 (Figure 1). The mosque builds upon the historical sourcing of architects like Chadirji, but, following the example of ElWakil, the al-Noor mosque narrows its range of references to a particular imperial architecture. Here the reference is Ottoman rather than Mamluk. With special emphasis on the single example of the mosque of Shezade Mehmet (1543-1548), Masjid al-Noor assembles a set of visual symbols that have been developed over time to represent spaces of pious congregation in Islam. In a conservative vernacular sense, Masjid al-Noor loosely replicates the Shezade Mehmet mosque, and its centralized plan is in line with the composition of the Imperial Ottoman mosques of Sinan Pasha. Masjid al-Noor retains the symmetry and a centralized prayer hall to its fullest extent, and, while remaining faithful to historic Ottoman forms, extends symmetrically along both horizontal and longitudinal axes of the prayer hall. The mosque's location in a garden overlooking the Khaled lagoon allows for complete views of its facades. Frontal axiality of the type used here was not widespread in the architectural traditions of the Islamic world, since it demands the often unavailable luxury of ample surrounding space ${ }^{5}$. Masjid al-Noor follows directly in the footsteps of El-Wakil's Jeddah mosques, not only in its faithfulness to a particular Islamic antecedents, but also in it use of contemporary building techniques. Masjid al-Noor introduces to the field of mosque construction pre-fabricated 
elements and new building technologies. With its explicit references to imperial Ottoman architecture, the mosque also repudiates narrowly nationalist and post colonialist agendas, instead suggesting a wider Islamic remit for contemporary mosques regardless of their location. The reverence for the classical Muslim past that informed $19^{\text {th }}$ century revivals is clearly no longer present here, just as the idealized nationbased citizen implicit in older institutions has been replaced by today's alienated and geographically mobile individual.

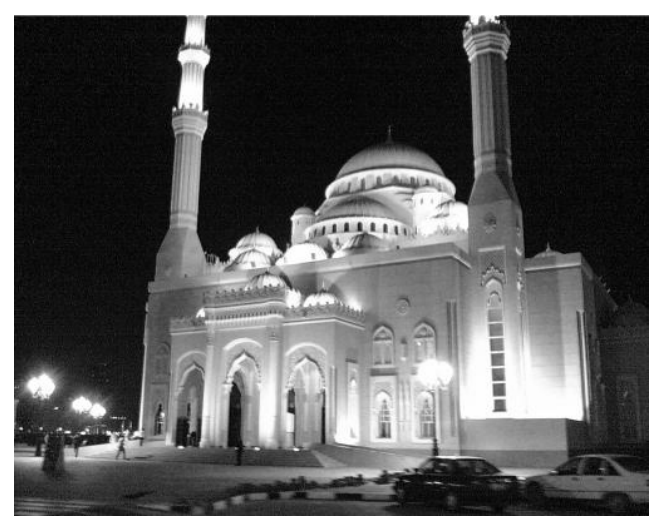

Figure 1. Masjid al-Noor street façade

Masjid al-Noor incorporates traditional decorative themes and religious signs common to the Muslim community in Sharjah, preserving the overall proportions of architectonic elements, but executing these in alternative materials. These clearly signal a space of cultural and religious commonality within the overarching modernity of the Dubai-Sharjah metropole. Set amidst an open landscape that connects the Islamic Bazaar, a traditional coffee house, and other public activity spaces, Masjid al-Noor is the focal point of an urban assemblage that functions as a hub for the gathering of Arab expatriate families. These three buildings represent much different approaches to insertion of 'Islamic' styled buildings into the modern city. The Islamic Bazaar is a modern vaulted building, which unexpectedly merges local architectural expressions, in the form of symbolic wind-towers, with exterior tiling of a type commonly featured in historic monuments of central Asia. The traditional coffee shop uses coral stone and local wind towers to produce an entirely local effect. Amidst the towering residential buildings and bustling traffic, the al-Noor congregational mosque is essentially a modern Ottoman facsimile.

With its overall consistency and sense of fidelity as a "whole" facsimile singularly visible across the flat terrain, it integrates the other buildings and surrounds into a coherent spatial organization. As a modern mosque sponsored by the state, set in a spatial composition of eclectic sources, it expresses an awareness of the varied semiotics historically brought together in the imperial mosques from which it originated. These include pencil shaped minarets, balanced stratification of the superstructure, a pyramidal cascade of main dome on smaller domes, a central baldachin -. all of which all pay tribute to an Ottoman imperial tradition associated with sacred space. At the same time a modern mosque, Masjid al-Noor recognizes that its social-rituals are limited to purely religious functions, since it is no longer associated with the broader social functions surrounding religious complexes of the past. These included schools (madrassas), hospital (bimaristans), caravansaries, and soup kitchens - all of which today have become spatially independent of religious buildings ${ }^{6}$. As part of the greater Sharjah Corniche, Masjid al-Noor anchors an urban assemblage that projects a range of architectonic elements a cultural signs of Islamic community, but does so in the context of unselfconsciously contemporary activities engaged in by the Arab expatriate residents living in the area.

\section{Masjid al-Maghfira, Heritage and Modern re-assemblage}

Along the Corniche of Sharjah, near Masjid alNoor, Masjid al-Maghfira is an example of an alternative approach to constructed heritage for a building of the same function (Figure 2). In contrast to the Masjid al-Noor, with its loose fidelity to a single historical exemplar, Masjid al-Maghfira harnesses fragmented units of Moorish Hispanic ornament. These maintain their proportions, and in that sense they too have preserved their origins. However, in this mosque example, the overall composition is eclectic and hybrid a type of modern vernacular. Masjid al-Maghfira mixes different elements of Umayyad monuments in Spain, the horseshoe arches and interlacing arches are visible on the facades and interior of the Great Mosque of Cordoba (784-6, 961-6) and Madinat al-Zahra (936-76). The lattice-work above the arches reflects another time frame, as these are adopted from Alhambra $\left(14^{\text {th }}\right.$ century). In general, the Umayyad/Hispanic tradition confined tiles and tile mosaics to the lower parts of walls, and these were mostly of geometric in design. In the mosque of al-Qarawiyyn in Fez and Alhambra, for example, sharp contrasts of dark and light colours contour the range of star patterns to contrast projecting stucco patterns and calligraphy with geometrical complexity that ultimately referred to 
the mathematics of Ibn Al-Haytham and other scientists. Despite of the availability of sophisticated geometric principles for determining the spatial and formal characteristics of mosques, architects of the modern era have tended to follow a traditional twodimensional approach, primarily focusing on the application of geometry to surface patterns. In Masjid alMaghfira, we can see this bias in how Alhambra's stucco patterns, horseshoe arches and muqarnas elements have been de-assembled and re-assembled in varying ways on the exterior surfaces of this apparently modern version of the Umayyad/Hispanic mosque (Figure 2).

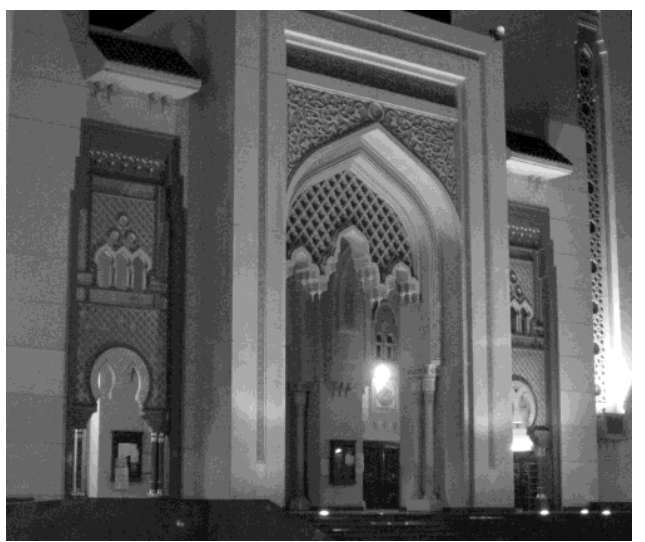

Figure 2. Masjid al-Maghfira entrance façade and portal

To complicate this, however, the twin minarets framing the main façade of Masjid al-Maghfira begin to depart from Moorish Hispanic examples. Here, the minarets transform vertically from square to octagon to cylinder, and on though an open columned upper section. They finally end with a bulbous top making explicit reference to Mamluk monuments in Egypt. The open roundels above the Moorish lattice work further strongly suggest late Mamluk mosques such as the funerary complex of Qaitbay (1472-4). This eclecticism and stylistic fragmentation, and the general blurring of stylistic boundaries, continues on the interior of the mosque. Given the Spanish Umayyad decorative approach taken on the exterior, and especially the direct references to the great mosque of Cordoba, one might have expected an interior of colourful mosaics similar to those in Cordoba. Here, however, different and contrasting colours of marble panels and their decorative assemblages are clearly derivative of buildings built centuries later, such as the madrassa of Sultan Hassan (1356). Overall, Masjid al-Maghfira demonstrates that contemporary architects can convincingly employ decorative patterns, open lattice work, and various stone and marble pa- nels to generate a building with coherent architectonic qualities that merge historical references from multiple sources with a compositional freedom inherited from the more recent modernist aesthetic.

Taken together, Sharjah's neo-Ottomanized mosques such as Masjid al-Noor, and the semiAndalusian Masjid al-Maghfira both use typically centralized plans. They also use the most visually important components of many mosques, with domes and minarets employed to their fullest extent in the articulating their historically derived façade compositions. Equally compelling from the Corniche boulevard along the Sharjah water front, and sharing an obvious reverence for Islamic architectural precedent, as well as similar planimetric strategies, these mosques however depart from one another in their manifestly different senses of appropriate limits of temporal and geographic reference, with the Masjid al-Maghfira taking a much more eclectic approach overall. In mapping out alternate strategies of reconstructing the past, Masjid al-Maghfira and Masjid al-Noor together capture the Corniche of Sharjah's pervasive sense of pluralism as an interpretative ideology of culture, and its broad sense that the merging of the 'local' and the 'regional' can be accomplished inclusively in a modern context.

\section{Museum of Islamic Civilization and Al-Qasbah; social space beyond the sacred}

The recently completed Museum of Islamic Civilization takes a similar approach, but this time in the context of a cultural institution with an explicitly Islamic mandate. The building initially references the Dome of the Rock with its gold coloured dome and distinctive tiled drum pierced with arched windows. The solid form in the Dome of the Rock below the drum, however, necessitates a less imitative approach. This is dictated by the building's dual functions as both a bazaar and museum. In contrast the Dome of the Rock, the Museum of Islamic Civilization achieves a necessary openness at this level by employing a double arched entrance which offers a strong link to traditional Ottoman bazaars and Caravansaries. The single dome in the centre with its transition zones draws on Ottoman traditions originally developed to resolve forces flowing from the dome to a square base and columns using pendentives. The Museum of Islamic Civilization's use of blind niches with alternating strips of stone in red and black further demonstrate the degree to which traditional motifs can be re-orchestrated well beyond the constraints of the time and space of Andalusian Islam from which they originated. A strong visual connection 
is also made to the recently restored caravanserai of Rustam Pasha. Here, stone work was patterned in alternating bands to display differences in stone colour outlining architectural shapes and forms, and this same strategy appears in the Museum. However, such polychrome panelling in stones and marbles have deep historic roots that extend well beyond the times and spaces of Ottoman and Mamluk monuments. These were, for example, especially popular in Byzantine buildings, and their use in the Museum reinforces a sense of expansive and inclusive historical referencing. This is also suggested by the use of large arched windows covered with grills combined with smaller arched windows on the upper floor, which are classical combinations found in vaulted structures across a wide range of Muslim monuments.

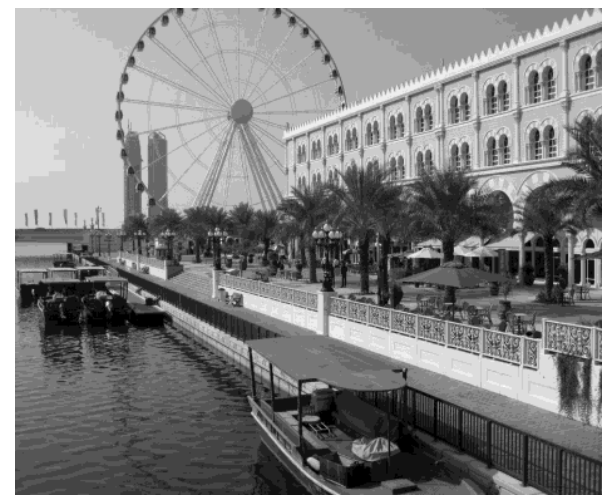

Figure 3. Al-Qasbah

Spatially, the Museum is divided into several galleries devoted to exhibiting artefacts and activities of Islamic craftsmen throughout the 13th and 14th centuries. Significantly, this was a period when increasing artistic exchanges took place between East and West in the Muslim World and Europe. By the very time frame chosen for the exhibited artefacts, the importance of Gulf is emphasised as the site of a highly fruitful successful meeting of East and West. The choice of this period, and the display of myriad artefacts resulting from it, emphasizes a more general sense of movement, exchange, and cultural mixing precisely what is experienced deeply and intimately in the lives of Arab expatriates who make up the majority of its patrons. Although the museum as a public monument in general has frequently become the means through which the relationship between the individual as a citizen and the State can be reconceived $^{7}$, what is more significant in the Museum of Islamic Civilization is its very obvious determination to forge a sense of Arab and Islamic commonality. It is clear that the principle design challenge taken up by this waterfront complex involves the question of how to support a cohesive social identity by combining a vibrant public life with broad references to a shared Islamic heritage - but doing all this in some thoroughly modern way.

In a more quotidian mode than those offered by Masjid al-Maghfira, Masjid al-Noor, or the Museum of Islamic Civilization, Al-Qasbah offers Sharjah yet another kind of shared cultural space seeking to address this same problem (Figure 3). Here, along an open air spine formed by a man-made canal and a promenade for pedestrians, Al-Qasbah connects two of Sharjah's lagoons in a highly eclectic space featuring commercial buildings with a vaguely Moorish Hispanic appearance. Again, although contemporary academic theory might suggest a more cohesive stylistic order, in Al-Qasbah Roman/Corinthian columns interlace with Andalusian horseshoe arches and stepped crenulations in a highly eclectic assemblage. In response to gentrifying pressures in the city, as well as a quest for some form of shared identity, the ultimate success of Al-Qasbah as a social space lies in its accessibility and practicality coupled with its wide range of shared imagery. All this suggests the outlines of an alternative model for supporting commercial activity that does not follow the example of Dubai's dreamscapes, theme malls, and other elite spaces of exclusion. The Qasbah and the Museum are both clearly examples of how contemporary architecture can incorporate the abstract qualities of a building, such as massing, solids and voids, sense of space, and structural principles in their reinterpreted forms, while further utilizing a vast range of decorative resources, to suggest in total a shared Islamic heritage. Both Al-Qasbah's and the Islamic Museum's mix of functional and symbolic elements effectively reinforce in their users an overarching but nonspecific sense of being "Arab" -of being recognizably a member of a widely dispersed and yet culturally specific community. Masjid al-Maghfira and Masjid alNoor also operate in ways similar to these two secular buildings. Beyond their more prosaic and sacred functions, the congregational mosques - as privileged buildings of culture - are recognizably cultural sign assemblages signally shared political virtue and Muslim identity. As such, the neo-Islamic buildings arrayed along Sharjah's Corniche carry out very broad and unmistakeably ideological tasks. 


\section{Conclusion: Neo Islamic Urbanism and the Living City}

In Sharjah, globalization and a general blurring of temporal and spatial boundaries have allowed monuments to "travel" freely in time and space. Among other things, this has lent them the potential to act as cultural ambassadors framing the city through a particular visual identity that is necessarily hybrid and geographically broad. In a sense, although the global conditions are different today than they were in the various pasts mapped by the great monuments of Islam, there has always something "plural" in the forms and expressions of Islamic architecture. This is obviously true in the sense that the geometries, forms and ornaments shaping and reshaping Muslim monuments were never frozen in time or space. As early as the seventh and eighth centuries, elements such as Corinthian columns and mosaics adopted from the built traditions of Byzantium can be found combined with horse-shoe arches and other disparate elements in the great mosque of Cordoba, in the Dome of the Rock in Jerusalem, and in the Great Mosque of Damascus. Over time, monument age and history have made such forms of eclecticism both familiar and acceptable. In a very real sense, this stylistic eclecticism and spatiotemporal "travel" have been crucial components of Arab-Islamic identity almost since the birth of Islam itself. Throughout history, architectural production in the Islamic world has taken an inclusive and flexible approach, largely unlike the situation encountered in the European Renaissance and in the Gothic period before that. Along with geometric analysis of extant buildings, and the textual description of travellers and writers, decoration in Islamic art has been one of the unifying factors that for thirteen centuries have linked buildings of Muslim communities to a broader sense of an Islamic identity well beyond geographic boundaries, from the Mughal Empire in the Far East to Andalusia in the West. In spite of the many criticisms levelled at Orientalism, representational works of Orientalist artists in the 19th century that depicted building traditions and architectural fragments did indeed offer resources for reconsidering and developing an appreciation for context and detail in Arab architecture. In this sense they supplied one means, however partial, for connecting various strategies that could be replicated in a larger modernist project to create a distinct modern-Islamic form of social life. Indeed, many traditional monuments of Muslim communities are studied from descriptions and representations of the arts of Islam by Orientalist artists and architects such as Owen Jones (1842-5), Pascal Coste (1818-1837), Prisse d'Avennes (1877), David Roberts (1838-1840) and others. These artists offer detailed drawings of Muslim monuments, effectively acting as a significant set of references for the construction, restoration and reconstruction of tradition, and identifying fragments that could then be easily recomposed in a diversity of contexts. The shear density of detail included in these semi academic references has made them significant resources in the construction of modern/neo-Islamic monuments. It is not incidental that they have helped fuel the plural narratives of Muslim dynastic pasts that have been used to express a broad range of Muslim community. Given the inherently pluralist and eclectic nature of Islamic form and ornament from the earliest years of Islam up until the Orientalist projects of the nineteenth century, and after, it should be clear that the complex eclecticism of the Sharjah Corniche is paradoxically entirely traditional. Lamentations about the deplorably pastiche quality of buildings like these entirely miss the point. Indeed, many supposedly superior urban design approaches and abstract principles derived from late neo-classicism and twentieth century modernism tend to divorce form from social and cultural contents to the point that projects along these lines fail to satisfy both current representational functions related to legitimate political agendas, and broader cultural demands for identity, community and continuity.

Neo-Islamic design strategies operating as alternatives to architectural modernism in the Arab world are obviously not unique to Sharjah. The Agha Khan awards program, for example, seeks to recognize modern/Islamic projects which incorporate similar strategies for achieving genuine spatial and architectural experience ${ }^{8}$, and which might carry the potential for applicability across the Islamic world. Homi Bhabha, for one, has made a strong case for broadly eclectic strategies as means of countering simplistic and constraining models of identity that chafe under conditions of changing expectations, new and emergent patterns of life, or fundamentally excluded modes of being. He argues for pulling the local/traditional and the global/contemporary together through similar strategies of hybridity by which fragments are assembled into new but contingent and "impure" wholes'. Along the Sharjah Corniche, a collection of neo-Islamic monuments and social spaces together comprise a complex strategy that champions continuity in aggregation along the dimensions both of cultural identity and architectural form. Here, we see 
the outlines of a new kind of Arab-Islamic authenticity, rooted neither in a mimicry-driven nostalgia for a lost past, nor uncritically embedded in a global modernity not of its creation. Along the Sharjah Corniche, a new kind of contingent social life is taking shape in the folds of a neo-regional urbanism that in its own way gathers the dispersed geographic origins, temporal dislocations, religious and cultural heritages, and regionally specific social interactions and that its local expatriate populations live every day.

Speaking in particular of architectural expression, the philosopher Hans-Georg Gadamer once commented that just as the architectural monument "poses the task of integration of past and present", it is the unique role of its "ornament, a background mood, or a framework" to "draw the attention of the viewer to himself ....and then to redirect it away from itself to the greater whole of the content of life which it accompanies"10. With fragments from across the many times and places of Islam, and with support for the various practical, spiritual and cultural activities engaged in by the residents of Sharjah, this is precisely the role that the Sharjah Corniche takes upon itself to play. As such, this urban complex stands as an admonition to those who have given up on the possibility of any genuine and lived authenticity in the contemporary Arab city.

\section{References}

1 S. Al-Radi. 1994. "Cornish Mosque" Architecture for Islamic Societies Today, James Steele ed.

2 S. Özkan. 1989. Regionalism within Modernism. In Space for Freedom. Ismaïl Serageldin (ed.). London: Butterworth Architecture.

3 J. Urry. 2002. The Tourist Gaze, London: SAGE Publications Ltd.

4 G. Edson. 1991. Heritage: Pride or Passion, Product or Service? International Journal of Heritage Studies, Vol. 10, No. 4, pp. 333-348.

5 M. Al-Asad. 2002. "Applications of Geometry", in Martin Frishman \& Hasan-Uddin Khan (Eds.) The Mosque History, Architectural Development and Regional Diversity. London: Thames and Hudson.

6 M. Arkoun. 2002. The Mosque History, Architectural Development and Regional Diversity. ed. Matin Frishman \& Hasan-Uddin Khan.

7 C. Duncan. 2005. "The Art Museum as Ritual", Heritage, Museums and Galleries, Gerard Corsane, ed. Routledge, pp.78-88.

8 S. Özkan. 1989. Regionalism within Modernism. In Space for Freedom. Ismail Serageldin (ed.). London: Butterworth Architecture.

$9 \mathrm{H}$. Bhabha. 2004. The Location of Culture. London: Routledge.

10 H-G. Gadamer. 1997. "The Ontological Foundation of the Occasional and the Decorative", in Neil Leach (Ed.) Rethinking Architecture, London: Routledge. 